\title{
Sowing date and maturity groups on the economic feasibility of soybean-maize double summer crop system
}

\author{
Épocas de semeadura e grupos de maturação na viabilidade econômica da \\ sucessão soja-milho safrinha
}

\author{
Karine Fuschter Oligini ${ }^{1}$ (D), Vanderson Vieira Batista ${ }^{1}$ (D), Elisa Souza Lemes ${ }^{1}$ (D), \\ Érik Januário da Silva² (D), Paulo Fernando Adami² (1) \\ 1Universidade Tecnológica Federal do Paraná (UTFPR), Pato Branco (PR), Brasil. E-mails: karine_oligini@hotmail.com; \\ vandersonvbatista@hotmail.com; lemes.elisa@yahoo.com.br \\ ¿Universidade Tecnológica Federal do Paraná (UTFPR), Dois Vizinhos (PR), Brasil. E-mails: eriksilva@utfpr.edu.br; \\ pauloadami@utfpr.com.br
}

How to cite: Oligini, K. F., Batista, V. V., Lemes, E. S., Silva, É. J., \& Adami, P. F. (2021). Sowing date and maturity groups on the economic feasibility of soybean-maize double summer crop system. Revista de Economia e Sociologia Rural, 59(4), e235472. https://doi.org/10.1590/1806-9479.2021.235472

\begin{abstract}
The success of soybean-maize double summer crop is very dependent on the sowing date and relative maturity group of cultivars. This study aimed to evaluate the economic feasibility of the adoption of soybean-maize double cropping under different sowing periods and soybean maturity groups. The production data used were obtained from two summer growing seasons (2016/17 and 2017/18) in an experiment carried out at Dois Vizinhos-PR, Brazil. The economic feasibility of each treatment was evaluated through the indicators of gross revenue, gross margin, operating profit, and profitability index. Soybean-maize succession is viable and presents positive profitability. Soybean establishment on October $15^{\text {th }}$ makes it economically unfeasible to sow maize (outside the zoning) as a $2^{\text {nd }}$ summer crop. Soybean maturity groups from 5.1 to 5.3, when sown on October $1^{\text {st }}$ allow profitability and better financial balance, being this combination the most suitable for a double summer crop. Soybean genotypes with maturity group 6.0 are an option for sowing in the middle of September, being the most lucrative and efficient arrangement, providing maize sowing in the middle of February, within the agroclimatic zoning of the region.
\end{abstract}

Keywords: agricultural zoning, profitability, crop production costs.

Resumo: O sucesso da sucessão soja-milho safrinha é muito dependente da data de semeadura e do grupo de maturação das cultivares. O objetivo deste estudo foi avaliar a viabilidade econômica da adoção da sucessão soja-milho safrinha sob diferentes épocas de semeadura e grupos de maturação de soja. Os dados de produção foram coletados nas safras de 2016/2017 e 2017/2018, em um experimento conduzido em Dois Vizinhos (PR), Brasil. A viabilidade econômica de cada tratamento foi avaliada por meio dos indicadores receita bruta, margem bruta, lucro operacional e índice de lucratividade. O sistema de sucessão soja-milho safrinha é viável e apresenta rentabilidade positiva. A semeadura da soja, em 15 de outubro, inviabiliza economicamente a semeadura da cultura do milho (fora do zoneamento) como segunda safra de verão. Grupos de maturação de soja de 5,1 a 5,3, quando semeados em início de outubro, permitem, além da lucratividade, melhor equilíbrio financeiro e menos risco produtivo, sendo essa combinação a mais indicada para a sucessão soja-milho safrinha. Genótipos de soja com grupo de maturação 6,0 é uma opção para semeaduras de abertura de zoneamento, sendo o arranjo mais lucrativo e eficiente, proporcionando a semeadura do milho em meados de fevereiro, dentro do zoneamento agroclimático da região.

Palavras-chave: zoneamento agrícola, lucratividade, custo de produção. 


\section{Introduction}

Agribusiness plays a major role in Brazilian's gross domestic product (25\% of GDP) since the country stands out among the world's largest grain producers and exporters. Soybean crop alone represents almost half (49\%) of the total cultivated area with annual crops and its importance keeps growing year after year (Associação Brasileira das Indústrias de Óleos Vegetais, 2018). Maize, comes in sequence, due to its importance along with soybean in the animal crude protein industry, besides its industrial and energy use potential (Escola Superior de Agricultura Luiz de Queiroz, 2015).

Farming crop systems have gone through several changes over the last few years. Nowadays, grow only one crop per year or keep growing the soybean-wheat succession has lost area to the soybean-maize double summer crop system, where maize grown in the offseason corresponds to $73 \%$ of the total corn produced in Brazil (Companhia Nacional de Abastecimento, 2019).

This arrangement is one of the most promising strategies to raise land yield and the potential of farmland resource use. Beyond being commodities, soybeans and maize are complementary crops where the cultivation of maize as a second summer crop allows the rotation of chemical defensives, facilitating the control of weeds by the fact that it allows the cultivation intercropped with Urochloa.

Nevertheless, this approach is complex and requires careful planning due to the climatic and economic vulnerability of the second crop (Galvão et al., 2015), especially in the south of Brazil. It is worth noting that planting maize in many regions becomes a risky activity due to climatic adversities, such as water deficiency and early frost during the crop development cycle, especially in late sowing crops, which prolongs their development and subjecting plants to possible situations of environmental risks. Consequently, this leads farmers to adjust the soybean/maize cycle, beginning with the sowing season of the appropriate soybean cultivars and maturity group, choosing earlier cultivars, for example (Silva Neto, 2011).

Therefore, understanding the production chains, as well as production costs, real profit, and the agricultural market, observing the prices of commodities, to identify the best time to market their production is a determining factor for the maintenance of this sector, relating economic, social, and sustainable development (Zanella \& Leismann, 2017). According to Carvalho et al. (2016), the financial monitoring of all agricultural activity allows obtaining data for decision making and verifying the profitability and viability of future productive arrangements. Economic feasibility analysis of a project is the first instrument to be measured for decision making on the investment, presenting the positive and negative points of the system (Seibert et al., 2014).

In the literature, there is a preference for studies with an economic focus to evaluate soybean and corn crops individually (Kamali et al., 2017; Robusti et al., 2019; Garbelini et al., 2020). Thus, these studies usually consider only one crop, instead of the double summer crop system, in which, different sowing date possibilities of each crop may greatly affect the economic result (Melo et al., 2012; Volsi et al., 2020). Other studies evaluated the technical performance of the different sowing dates for these crops (Arakaki \& Minuzzi, 2016; Garcia et al., 2018), but do not quantify the economic result that this arrangement can result. Few studies address both themes in the same study, such as Battisti et al. (2020), which analyzed the best combination of production and profitability considering different sowing periods of soybean and corn crops in the double summer crop succession. However, Battisti used computerized sowing simulation models, which can generate variations with the results obtained in studies developed in the field.

This lack of practical studies that address the economic results and the sowing dates of soybean and corn crops in succession shows a knowledge gap to be filled. Economic/financial studies on the possible arrangements among genotypes and sowing dates of the soybean/maize crop are fundamental in the search for a profitable balance between them. In this way, perhaps, the idea is not to seek for maximum soybean and/or maize individual income, but rather, a combination that allows the best economic return of the cropping system. 
This study aimed to: a) evaluate the economic viability of soybean-maize succession; b) assess the arrangement of different soybean maturity groups and sowing dates on the final result of the double summer crop system, and c) identify the combination of soybean and maize as a $2^{\text {nd }}$ summer crop of greater economic results for the region.

\section{Materials and Methods}

Data used in this study were obtained from a field trial with soybean-maize doublecropping during two summer growing seasons (2016/17 and 2017/18). The study was carried out at the Universidade Tecnológica Federal do Paraná, the campus of Dois VizinhosAgricultural Research Station, located at $25^{\circ} 41^{\prime}$ latitude south, $53^{\circ} 05^{\prime}$ longitude west and 526 $\mathrm{m}$ above sea level. The soil at the experimental site is classified as a Clayey Oxisol (Bhering et al., 2012). The climate is classified as CFa (humid subtropical) without a distinct dry season (Alvares et al., 2013).

The experiment occurred from September 2016 to July 2018, under a no-tillage system. The experiment design was a completely randomized block with three replications, consisting of 18 treatments as noticed in Table 1 . In the same table, it is verified the maturity groups and sowing dates used for the soybean crop.

Table 1. Scheme of the treatments, composed of different sowing dates of soybean and maize over the 2016/17 and 2017/18 growing seasons. Dois Vizinhos-PR, Brazil, 2020.

\begin{tabular}{|c|c|c|c|c|c|}
\hline Treatment & $\begin{array}{c}\text { Soybean } \\
\text { sowing date }\end{array}$ & MG - Soybean & $\begin{array}{l}\text { Maize sowing } \\
\text { date }\end{array}$ & $\begin{array}{c}\text { Soybean } \\
\text { yield }\left(k_{g} \text { ha }^{-1}\right)\end{array}$ & $\begin{array}{c}\text { Maize yield } \\
\left(\mathrm{kg} \mathrm{ha}^{-1}\right)\end{array}$ \\
\hline $\mathrm{T} 1$ & 09/15/16 & 5.0 & $01 / 16 / 17$ & 3358.53 & 9385.19 \\
\hline $\mathrm{T} 2$ & 09/15/16 & 5.1 & $01 / 22 / 17$ & 4124.83 & 9204.93 \\
\hline T3 & 09/15/16 & 5.3 & $01 / 26 / 17$ & 4196.27 & 8450.22 \\
\hline $\mathrm{T} 4$ & $10 / 01 / 16$ & 5.0 & $01 / 30 / 17$ & 3772.97 & 7692.02 \\
\hline T5 & $10 / 01 / 16$ & 5.1 & $02 / 06 / 17$ & 4468.90 & 6616.53 \\
\hline T6 & $10 / 01 / 16$ & 5.3 & $02 / 09 / 17$ & 4423.47 & 6477.99 \\
\hline $\mathrm{T7}$ & $10 / 15 / 16$ & 5.0 & $02 / 15 / 17$ & 4075.53 & 2577.84 \\
\hline T8 & $10 / 15 / 16$ & 5.1 & $02 / 20 / 17$ & 4065.53 & 2316.29 \\
\hline T9 & $10 / 15 / 16$ & 5.3 & $02 / 23 / 17$ & 5014.83 & 4770.56 \\
\hline $\mathrm{T} 10$ & 09/15/17 & 5.1 & $01 / 23 / 18$ & 3399.53 & 8461.95 \\
\hline T11 & 09/15/17 & 5.3 & 02/06/18 & 4697.21 & 7208.24 \\
\hline T12 & $09 / 15 / 17$ & 6.0 & 02/09/18 & 5972.45 & 7608.56 \\
\hline T13 & $10 / 01 / 17$ & 5.1 & $02 / 15 / 18$ & 5841.24 & 7039.88 \\
\hline T14 & $10 / 01 / 17$ & 5.3 & $02 / 18 / 18$ & 5596.51 & 6869.93 \\
\hline T15 & $10 / 01 / 17$ & 6.0 & $02 / 23 / 18$ & 6205.54 & 6121.76 \\
\hline T16 & $10 / 15 / 17$ & 5.1 & $02 / 28 / 18$ & 5184.79 & 6046.34 \\
\hline $\mathrm{T} 17$ & $10 / 15 / 17$ & 5.3 & 03/03/18 & 4778.99 & 5670.00 \\
\hline T18 & $10 / 15 / 17$ & 6.0 & 03/15/18 & 4917.35 & 4800.62 \\
\hline
\end{tabular}

MG: maturity group.

Soybean cultivars used were P95R72 RR ${ }^{\circledR}$ (maturity group: 5.0), P95R51 RR ${ }^{\circledR}$ (maturity group: 5.1), and P95Y52 RR ${ }^{\circledR}$ (maturity group: 5.3 ) in 2016/2017 growing season and P95R51 $\mathrm{RR}^{\circledR}, \mathrm{P} 95 \mathrm{Y} 52 \mathrm{RR}^{\circledR}$, and P96Y90 $\mathrm{RR}^{\circledR}$ (maturity group: 6.0) in 2017/2018 growing season. The change in P95Y72 soybean cultivar to P96Y90 occurred due to the low yield presented by P95Y72. Maize hybrid P3431VYH was sowed on the same day as soybean cultivars were harvest.

Crops seeding were performed with a no-till seed-fertilizer drill with 5 rows. Thus, the experimental units consisted of 10 rows of $30 \mathrm{~m}$ long, having 10 meters among blocks, to facilitate the maneuvers of the tractor - seeder. 
Both crops were sowed with $0.45 \mathrm{~m}$ row spacing. Population density for soybean crop was established according to the technical recommendations required by each cultivar. Corn hybrid was sowed at a seed density of 66,000 seeds ha-1.

Base fertilization used in the two growing seasons was the same. For the soybean, fertilization consisted of $500 \mathrm{~kg} \mathrm{ha}^{-1}$ of the formula 05-11-09 $\left(\mathrm{N}-\mathrm{P}_{2} \mathrm{O}_{5}-\mathrm{K}_{2} \mathrm{O}\right)$, and potassium was broadcast after sowing using potassium chloride at $120 \mathrm{~kg} \mathrm{ha}^{-1}$ for production expectation of 5 tons of soybean. Fertilization in the maize furrow was performed with $327 \mathrm{~kg} \mathrm{ha}^{-1}$ of the formula 02-18-18 $\left(\mathrm{N}-\mathrm{P}_{2} \mathrm{O}_{5}-\mathrm{K}_{2} \mathrm{O}\right)$ and nitrogen was topdressing as urea at the rate of $100 \mathrm{~kg}$ of $\mathrm{N} \mathrm{ha}^{-1}$, for meeting the production expected of $9,000 \mathrm{~kg} \mathrm{ha}^{-1}$.

Weed control in post-emergence of soybean and maize crop, as well as pests and diseases, were carried out based on scouting, applying the agrochemicals according to the technical recommendations (Brazilian Agricultural Research Corporation- Embrapa) and products labels for both crops.

Soybean yield was assessed by harvesting two samples of three rows $5 \mathrm{~m}$ long (sample area of $6.75 \mathrm{~m}^{2}$ of each point) per plot, while corn was harvested the spikes at the two central rows $5 \mathrm{~m}$ long, in two points per plot. These samples were threshed and the grains weighed, correcting their moisture content for $13 \%$ and the values were transformed into $\mathrm{kg} \mathrm{ha}^{-1}$.

The production costs of soybean and corn crops for each growing season are shown in Table 2. Determination of the agricultural cost activity was made based on the effective operating cost using the methodology described by Martin et al., 1998, from the Institute of Agricultural Economics, which prescribes that operating costs include operating expenses, expenses with operations carried out by the third part company and expenses with materials consumed. Operating expenses were calculated using Equation 1.

$O C=H^{*} C^{*} P$

Where $\mathrm{OC}$ are the values of the expenses with operations, $\mathrm{H}$ the number of hours allocated to each operation, $C$ the fuel consumption in the operation, and $\mathrm{P}$ the price of the fuel on the date that the operation was performed.

The expenses with inputs were calculated using the multiplication of the quantity used by the purchase price of the products.

Expenditure on labor considered the average monthly salary of a tractor operator published by SEAB - DERAL, divided by 24 working days and the result by 8 hours, to obtain the hourly rate. This final value was multiplied by the total number of hours the worker worked in the survey. No contract operations were carried out in this research.

All prices considered for inputs, fuel, and labor consumed refer to September 2016 values and obtained in establishments in the county where the experiment was installed. Unit bag price of the soybean and maize $(60 \mathrm{~kg}$ ) was stipulated based on the average of the last 10 years of the quotations of national cooperatives. Thus, the value of the bag was stipulated in 65.48 and $24.18 \mathrm{R} \$$ bag $^{-1}$ of soybean and maize, respectively, for both years of study (Formigoni, 2017).

To measure the economic viability of the production systems, we adopted the methodologies described by Matsunaga et al. (1976), Lazzarini Neto. (1995), and Martin et al. (1998), which were performed for both systems, as follow:

Gross Revenue: determining the revenue obtained as a result of the sale of the product.

$G R=Y^{*} P$

Where $Y$ is the productivity in bags per hectare and $P$ the selling price of a unit of the product.

Gross Margin (EOC): is the margin concerning the effective operating cost (EOC), that is, the result that remains after the producer pays the effective operating cost and concerning that same cost (in percentage) considering a determined unit sale price and income from the production for the activity. 
Table 2. Relation of production costs and inputs used to grow 1 hectare of soybean and maize as a second crop along two growing seasons. Dois Vizinhos- PR, Brazil, 2020.

\begin{tabular}{|c|c|c|c|c|}
\hline \multicolumn{5}{|c|}{ Production costs of soybean and maize in 2016/2017 and 2017/2018 growing season } \\
\hline Crops & \multirow{2}{*}{ Unit } & \multirow{2}{*}{$\begin{array}{c}\text { Soybean } \\
\text { R\$ ha-1 }\end{array}$} & \multirow{2}{*}{$\begin{array}{l}\text { Maize } \\
\text { R } \text { ha }^{-1}\end{array}$} & \multirow{2}{*}{$\begin{array}{c}\text { Succession } \\
\text { R\$ ha } \\
\text {-1 }\end{array}$} \\
\hline Activities & & & & \\
\hline A - Operation costs & & 111.83 & 120.90 & 232.72 \\
\hline Area Desiccation & - & 3.32 & 3.58 & 6.90 \\
\hline Sowing/Fertilizer & - & 23.68 & 25.60 & 49.28 \\
\hline Manag. Practices - Herbicide & - & 3.32 & 3.58 & 6.90 \\
\hline Manag. Practices - Insecticide & - & 3.32 & 3.58 & 6.90 \\
\hline Manag. Practices - Cover fertilizer & - & 3.32 & 3.58 & 6.90 \\
\hline Harvest & - & 53.28 & 57.60 & 110.88 \\
\hline Transport & - & 21.61 & 23.36 & 44.97 \\
\hline Labor Costs (2) & Hours & 12.70 & 12.70 & 25.40 \\
\hline B - Input Consumption Costs & & 1528.25 & 1891.14 & 3419.39 \\
\hline Desiccant & $\mathrm{L}$ & 30.00 & 25.50 & 55.50 \\
\hline Seeds & Bag & 319.00 & 748.24 & 1067.24 \\
\hline Cover Fertilizer & $\mathrm{Kg}$ & 292.50 & 373.50 & 666.00 \\
\hline Base Fertilizer & $\mathrm{Kg}$ & 541.45 & 381.50 & 922.95 \\
\hline Insecticide & $\mathrm{L}$ & 120.00 & 226.40 & 346.40 \\
\hline Post-Emergence Herbicide & $\mathrm{L}$ & 30.00 & 85.00 & 115.00 \\
\hline Preventative Fungicide & Bag & 95.00 & 0.00 & 95.00 \\
\hline Curative Fungicide & $L$ & 100.30 & 51.00 & 151.30 \\
\hline $\mathrm{EOC}(\mathrm{A}+\mathrm{B})$ & & 1652.78 & 2024.74 & 3677.52 \\
\hline
\end{tabular}

Manag: Management. EOC: Effective operating cost. (1) Calculated based on the average yield of the treatments in bags ha $^{-1}$; (2) Calculated based on monthly tractor operator salary (SEAB - DERAL); Source: Survey Data.

$G M(E O C)=((G R-E O C) / E O C) \times 100$

Where GR is the activity gross revenue and EOC is the effective operating cost.

Operating Profit (or liquid income): represented by the difference between gross revenue and effective operating cost per $\mathrm{ha}^{-1}$, expressed in $\mathrm{R} \$ \mathrm{ha}^{-1}$. The operating profit (OP) results indicator measures the profitability of the activity in the short term, showing the financial and operational conditions of the agricultural activity.

$O P=G R-E O C$

Profitability index: estimated by the relation between gross revenue and operating profit, given in percentage.

$P I=\left(\frac{O P}{G R}\right) * 100$

With the crop yield results obtained by field evaluations and in the calculation of the indicators already mentioned, the results were compared with those obtained in the specialized literature and the historical values cataloged in the region. 


\section{Results and Discussion}

\section{Analysis of the economic results of the treatments}

Results obtained from the economic values (Table 3) indicate that the soybean-maize double summer crop system is economically viable, since it generated positive results in all treatments, although, the data shows that maize yield is reduced as soybean harvest is delayed as a consequence of later sowing or longer cycle maturity group. In general, anticipated soybean sowing (Early September from $10^{\text {th }}$ to $15^{\text {th }}$ ) associated with shorter maturity groups (5.0 and 5.1), tend to result in lower economic returns to the soybean crop system, due to the low soybean yield. When compared to soybean sowed in early October (Table 3), the operating profit average value difference between these sowing arrangements and gross margin is $1164.16 R \$ h^{-1}$, showing better results when soybean is sowed the beginning of October. Moreover, by dividing the soybean value $(R \$ 65)$ to the maize value $(R \$$ 24) (Both bags of $60 \mathrm{~kg}$ ) we notice a ratio of 2.7. Considering maize's higher production costs, this ratio easily overcame the 3:1 relation. In other words, to each soybean bag yield reduced due to earlier sowing, farmers will have to harvest an additional of 3 bags of corn to compensate for the tradeoff between corn and soybean.

Table 3. Economic indicators of soybean-maize succession system in southern Brazil. Dois Vizinhos, PR, 2020.

\begin{tabular}{|c|c|c|c|c|c|}
\hline $\begin{array}{l}\text { Treatm } \\
\text { ents }\end{array}$ & $\begin{array}{l}\text { Total cost } \\
\text { (R\$ ha-1) }^{-1}\end{array}$ & $\begin{array}{l}\text { Gross Revenue } \\
\text { (R\$ ha-1) }\end{array}$ & $\begin{array}{c}\text { Gross Margin } \\
\qquad\left(\% \mathrm{ha}^{-1}\right)\end{array}$ & $\begin{array}{l}\text { Operating Profit } \\
\left(\mathbf{R} \$ \mathrm{ha}^{-1}\right)\end{array}$ & $\begin{array}{c}\text { Profitability } \\
\text { index }(\%)\end{array}$ \\
\hline $\mathrm{T} 1$ & 3677.52 & 7447.51 & 103 & 3769.99 & 51 \\
\hline $\mathrm{T} 2$ & 3677.52 & 8211.15 & 123 & 4533.64 & 55 \\
\hline T3 & 3677.52 & 7984.97 & 117 & 4307.45 & 54 \\
\hline $\mathrm{T} 4$ & 3677.52 & 7217.45 & 96 & 3539.94 & 49 \\
\hline T5 & 3677.52 & 7543.52 & 105 & 3866.01 & 51 \\
\hline T6 & 3677.52 & 7438.11 & 102 & 3760.59 & 51 \\
\hline $\mathrm{T7}$ & 3677.52 & 5486.63 & 49 & 1809.12 & 33 \\
\hline T8 & 3677.52 & 5370.31 & 46 & 1692.80 & 32 \\
\hline T9 & 3677.52 & 7395.39 & 101 & 3717.87 & 50 \\
\hline $\mathrm{T} 10$ & 3677.52 & 7120.19 & 94 & 3442.67 & 48 \\
\hline $\mathrm{T} 11$ & 3677.52 & 8031.14 & 118 & 4353.63 & 54 \\
\hline $\mathrm{T} 12$ & 3677.52 & 9584.18 & 161 & 5906.67 & 62 \\
\hline T13 & 3677.52 & 9211.81 & 150 & 5534.30 & 60 \\
\hline T14 & 3677.52 & 8876.24 & 141 & 5198.72 & 59 \\
\hline T15 & 3677.52 & 9239.38 & 151 & 5561.87 & 60 \\
\hline T16 & 3677.52 & 8095.01 & 120 & 4417.49 & 55 \\
\hline T17 & 3677.52 & 7500.48 & 104 & 3822.97 & 51 \\
\hline T18 & 3677.52 & 7301.12 & 99 & 3623.60 & 50 \\
\hline
\end{tabular}

Values referring to the sum of the indicators of soybean + maize.

The economic performance indicators of the treatments show a trend of better global results between $T 12$ and $T 15$, being the only ones with operating profits above $R \$ 5000.00 \mathrm{ha}^{-1}$ and profitability index above $60 \%$. These treatments clearly present a better economic balance between the conduction of both crops, with the predominance of higher productivity for the soybean crop, which has a higher sales value, together with a good performance for the corn crop, grown as a $2^{\text {nd }}$ summer crop (Table 1 ). This balance also guarantees for these treatments the best results in the other evaluated indicators.

Soybean maturity group 6.0 sowed in the middle of September, with corn sowing on January $09^{\text {th }}$ was the best arrangement. In this case, the performance of soybean contributed $67.51 \%$ of the system's gross income and its production costs are lower than corn. In general, 
the results show the importance of high soybean yield to achieve the best global results. Moreover, a longer maturity cycle may support better hydric stress periods, since it has more time to grow and compensate losses.

Another important point is the range of the results between treatments. As early as soybean is sowed, as higher is its yield, although, when it results in corn sowing later than February $15^{\text {th }}$, global results tend to show lower profitable values. The operating profit difference between T8 and T12 of approximately 3.5 times greater for T12 show how important it is to fit the right maturity group at right time. Moreover, regarding to the profitability index, T12 results were $30 \%$ higher than T8. Of course, this may change according to the weather conditions and sowing also depends on the weather, but it is a decision made that greatly impact farm results and due to it, should be considered at the decision time making.

Despite the positive result in all treatments, the values of the economic indicators were lower than those obtained by Garbelini et al. (2020), even with lower yields for both cultures in the evaluated harvests. What may explain this difference is the fact that the sale price of the products adopted in this research reflects the moment of planting the experiment, in September 2016 and the authors use the sale prices of the products in December 2018 in their work, considerably higher. Comparing with results obtained by Nóia Júnior \& Sentelhas (2019), they are equivalent, both in terms of the final productivity of each crop, as well as in the economic results, demonstrating a similar behavior of the results even in different municipalities adopted in each work.

In both works cited, the sowing of soybean at the beginning of September resulted in the highest economic result and the income from the soybean culture was predominant in the result of the system, as observed in this research. However, analyzing only the economic results of the treatments does not guarantee that they comply with the legislation and not evaluate the risks of obtaining the results presented, such as the occurrence of frosts, very common during the winter in the region, which requires a technical analysis of each treatment to assess its feasibility of application in the field. The combination of technical and economic evaluation demonstrates with greater precision which is the best arrangement of crops in succession most suitable for producers.

\section{Technical analysis of the treatment results}

According to Fietz et al. (2012), early sowing may impair soybean crop behavior, especially for early-cycle genotypes established at planting in early September. Trentin et al. (2013) observed in their studies that for the same region (the lower the maturity group, the lower the cycle), thus having a strong tendency to shorten vegetative and reproductive phase, which does not apply to higher maturity group.

Soybean genotypes with short maturity group sowed earlier in September end up having a photoperiod stimulus to flower and reach reproductive development faster, which associated with the lower temperature at this period of the year, may result in shorter plants with often low yield potential, which tends to be minimized as the cycle of the genotypes increases or sowing is delayed to October.

Of course, maize yield is as higher as earlier as it is sowed. As noticed in Table 3, maize yield reduces in the order of $201 \mathrm{~kg} \mathrm{ha}^{-1}$ per day of sowing delay from treatment 1 to treatment 8 at the first growing season. Thus, beyond maize yield reduction due to worse climatic conditions (shorter days with lower temperature and radiation), later sowing increases the risk of frost losses, which can compromise the system income.

Therefore, arrangements with soybean with 5.1 - 5.3 maturity group sowed at the beginning of October anticipated the sowing period of maize in succession, which is one of the objectives of farmers, with good yield potential and lower environmental risks (frosts) to the second summer crop cultivation reaching a productive equilibrium of both crops within the system.

Soybean genotypes with a longer maturity group (6.0) can compensate adverse climatic conditions (short photoperiod and lower temperature) once it has a longer period of vegetative growth, and due to it, but be a good option to sowing at the beginning of soybean 
zoning calendar (September $10^{\text {th }}$ ). In fact, the arrangement of 6.0 soybean genotype sowed on September $15^{\text {th }}\left(5972.45 \mathrm{~kg} \mathrm{ha}^{-1}\right)$ with maize $\left(7608.56 \mathrm{~kg} \mathrm{ha}^{-1}\right)$ sowed on February $18^{\text {th }}$ presented better economic results considering the double-crop system proposed.

This arrangement presented a higher gross revenue, gross margin, operating profit, and profitability index than the others, and a difference of GR and operating profit of 4,213.87 R\$ $\mathrm{ha}^{-1}$ concerning the worst treatment (Soybean sowed on October $15^{\text {th }}$ with maize sowed on February $20^{\text {th }}$, which yielded only $2316.29 \mathrm{~kg} \mathrm{ha}^{-1}$ ) (Table 3). This result is justified by the high soybean yield showed by this cultivar (maturity group 6.0) and sowing date, which contributed $82 \%$ of the operating profit of the succession. The greater cycle of this genotype generates a balance between the vegetative and reproductive stage due to a longer juvenile period, concerning the other genotypes (maturity group 5.1 - 5.3), resulting in taller plants with higher yield potential. In addition, it allows maize cultivation within the agricultural zoning and with a satisfactory return for the system, being one of the best option for farmers who prefer to adopt early sowings.

Soybean maturity group 5.1 and 5.3 (T13 and T14) sown on October $1^{\text {st }}$ with maize sowed on February $9^{\text {th }}$ and $15^{\text {th }}$, respectively, were the $3^{\text {rd }}$ and $4^{\text {th }}$ best treatments, with a mean GR of $9,044.02 \mathrm{R} \$ \mathrm{ha}^{-1}$ and $59 \%$ profitability index with $85 \%$ soybean participation and $14 \%$ maize in the total performance for both arrangements (Table 3). This shows once again the direct effect of the sowing period and the maturity group, and how soybean profit is important for the system.

These arrangements seem to be the most suitable treatments for the south of Brazil, because they have economic stability for both crops over time, with high soybean and maize yield with less climatic risks (frost). Analyzing the socio-economic relevance of soybean crop, as shown by the high percentage of participation in the economic results of the system (T13 and T14), the ideal combination for succession should always consider the importance of not compromising soybean productivity. Garcia et al. (2018) observed that soybean genotypes sown in early October show better productive performance, not justifying early or very late sowing for short-season cultivars.

Silveira et al. (2008) evaluated the production costs for summer and winter crops and reported a profitability index of 57.8 and $18.1 \%$ for soybean and maize crops respectively. These results are similar to those obtained in the present study, which is considered suitable for agricultural activity.

The treatment T15 and T18 is another situation presented by the economic indicators (Table 3), in which the use of a genotype of maturity group 6.0 sowed on October $1^{\text {st }}$ and $15^{\text {th }}$ resulted in maize sowing on March $03^{\text {rd }}$ or February $23^{\text {th }}$, respectively. This maize sowing date is out of the crop zoning, which reduces the adoption possibility of these arrangements, once there is no financial support for it. Even though, gross revenue and operating profit are high in these arrangements due to the good productive performance of soybean crop. Exceeding the final sowing date is a very large risk factor and has implications in cases in which the producer intends to finance the crop. The same can be applied to the maturity group of 5.3 in late sowing on October 15.

In addition, when comparing the results of T13 with that of T15, we observed that both result in a similar final profitability index $(60 \%)$ for the succession. However, looking beyond the numbers, T15 (with a soybean maturity group 6.0) ended up having maize second crop outside the indicated time of sowing, being in this situation preferable the adoption of shortseason genotype for this time, as in the case of T13.

We should consider that even in a troublesome agricultural year, due to some climatic adversity, such as severe droughts (as observed at the 2018/19 growing season), or excess precipitation, or seasonality of grain value in the market, succession system can have positive economic returns, which would not happen in a monoculture system.

Maize as a $2^{\text {nd }}$ crop may compensate, bringing financial stability and also environmental advantages (high amount of straw to the system) to the farmers, but it has a great dependence on the sowing period. The combination of maturity group 5.1 soybean sowed on October $15^{\text {th }}$ with maize sowed on February $20^{\text {th }}$ for example (Treatment T8) showed a gross margin of $46 \%$ and $-64 \%$ loss in total operating profit due to corn lodging and lower yield. It means that corn crop did not even cover production costs. 
Given this, it is advisable for the farmers to actually analyze the feasibility or proportion of the area that will invest with this arrangement/system since the risk of production is as important as the potential return of the system. By these results, we can say that double summer crop season is viable, but there are productive risks, and due to it and based on money availability, each farmer should evaluate how much (\%) of his area will be cultivated with this system.

The fact is that even with higher production risks, maize provides some benefits to the systems such as a high amount of straw of low degradability generating benefits such as nutrient cycling, and is an option for producers to strengthening crop rotation system. In general, this succession system is an interesting economical investment, it provides positive points for management as a whole, diluting the risk of injury from one or another crop, with short and long-term positive returns, but, anyway, it is suggested that farmers use the succession two years in sequence at most, and then, adopt other species, such as wheat or cover crops. We should highlighting that this is a crop succession and not a crop rotation system (where wheat, beans, oats, and cover crops should be added to the system), and due to it, with time, problems such as disease (especially stalk root disease), bugs, and weed pressure may increase (Vernetti Junior et al., 2009; Bennett et al., 2012; Andrade et al., 2017).

Soybean sowed on October $15^{\text {th }}$ reports a reality of farmers that sow the crop after wheat. This soybean sowing period makes maize growth unfeasible, having the most extreme scenarios as of February 18, and providing greater productive and economic risks. High maize grain yield is achieved through cultural practices, such as appropriate sowing season, which allows a greater capitalization for future activities, including the implantation of the next summer crop (Silva et al., 2015).

In this sense, the risk of production is as important as the potential for economic return. Therefore, the idealization of maize second crop in succession to soybean starts from the establishment of the summer crop, aiming to liberate the area as soon as possible (with low impacts on the productive potential of soybean), minimizing the reduction in maize yield potential when sowing is delayed, which leads to loss risks due to adverse conditions (drought and/or frost) (Cruz et al., 2006). Frost, depending on the intensity, may significantly affect the photosynthetic area of the leaves, reducing photoassimilates production for grain filling (Fancelli \& Dourado Neto, 2004; Fornasieri Filho, 2017).

Furthermore, as maize sowing is delayed, temperatures tend to decrease, which influences the number of days between each phenological stage of plants, lengthening the periods to the next stages. Unlike earlier sowing dates, in which plants find higher temperatures, providing less time between phenological stages, reaching earlier reproductive stages, thus reducing the frost loss.

Frost's risk at the southern is a worry and should always be considered. It may occur earlier or later in winter, but it usually occurs. Of course, it is more often to happen in July than in June or May. Aiming to report how frost can affect yield potential and economic performance, if a frost is hypothesized to the second week of May, for example, this would affect the area according to the sowing dates at different levels. Thus, maize sown in midJanuary would be at the R5 stage, a stage that precedes physiological maturity, resulting in a low yield loss.

On the other hand, maize sowed from January 22 to February 15, the plants would be mostly in the R4 stage, suffering a reduction of 10 to $15 \%$ in productive crop potential. As for the sowing at the end of February, the plants would be at the beginning of the reproductive stage (VT-R1), in which the grains are being formed, and the loss of photosynthetic area can result in a high yield loss.

In this way, it is prudent for the farmer to establish a plan of action, focusing on the best arrangements which should be recommended and adopted by the farmers; however, each growing season has its particularities, and due to it, we recommend that farmers adopt a plan with a combination between cultivars cycle and sowing period, reducing though production risks. It is important that beyond yield or profit of one crop, the system should be taken as a whole, and production cost, commodities market prices, and potential profit are always associated with production risks. In posse and considering all these data, decision-making will be more effective. 


\section{Conclusion}

Soybean-maize succession is viable and presents positive economic return. Soybean establishment on October $15^{\text {th }}$ makes it economically unfeasible to sow maize (outside the zoning) as the second summer crop. Soybean maturity groups from 5.1 to 5.3, when sown on October $1^{\text {st }}$ allow better financial balance, being this combination the most suitable for a double summer crop in southern Brazil. Genotypes with maturity group 6.0 are an option for sowing in the middle of September, being the most lucrative and efficient arrangement, providing maize sowing in the middle of February, within the agroclimatic zoning of the region.

\section{Acknowledgments}

The first author thanks the Coordenação de Aperfeiçoamento Pessoal de Nível Superior (CAPES) for granting the scholarship. The authors declare that have no conflicts of interest.

\section{References}

Associação Brasileira das Indústrias de Óleos Vegetais - ABIOVE. (2018). Exportações Brasileira de Soja 2018 é superior a 13\% comparado ao mesmo período de ago/2017. São Paulo, SP: MDIC/Secex ABIOVE.

Alvares, C. A., Stape, J. L., Sentelhas, P. C., Gonçalves, J. L. M., \& Sparovek, G. (2013). Köppen's climate classification map for Brazil. Meteorologische Zeitschrift (Berlin), 22(6), 711-728.

Andrade, J. F., Poggio, S. L., Ermácora, M., \& Satorre, E. H. (2017). Land use intensification in the rolling pampa, Argentina: diversifying crop sequences to increase yields and resource use. European Journal of Agronomy, 67(82), 37-51.

Arakaki, A. M., \& Minuzzi, R. B. (2016). Datas de semeadura para o cultivo em sucessão soja-milho safrinha baseadas na produtividade para as regiões de Maringá - PR e Chapecó - SC. Revista Brasileira de Agropecuária Sustentável, 6(4), 11-18.

Battisti, R., Ferreira, M. D., Tavares, E. B., Knapp, F. M., Bender, F. D., Casaroli, D., \& Alves Junior, J. (2020). Rules for grown soybean-maize cropping system in midwestern Brazil: Food production and economic profits. Agricultural Systems, 182, http://dx.doi.org/10.1016/j.agsy.2020.102850

Bennett, A. J., Bending, G. D., Chandler, D., Hilton, S., \& Mills, P. (2012). Meeting the demand for crop production: the challenge of yield decline incrops grown in short rotations. Biological Reviews of the Cambridge Philosophical Society, 87(1), 52-71.

Bhering, S. B., Santos, H. D., Manzatto, C. V., Bognola, I., Carvalho, A. P., Potter, O., \& Carvalho Junior, W. (2012). Mapa de solos do estado do Paraná. Rio de Janeiro: Embrapa Solos, 73p.

Carvalho, L. C., Esperancini, M. S. T., Santos, J., \& Ribas, L. C. (2016). Análise comparativa de estimativas de custo de produção e rentabilidade entre sojas RR1 E RR2 PRO/Bti. Revista Energia na Agricultura, 31(2), 186-191.

Companhia Nacional de Abastecimento - CONAB. Acompanhamento de safra brasileira degrãos: Safra 2018/19: sexto levantamento (Vol. 6, No.10). CONAB; 2019. Retrieved in 2019, July 12, from https://www.conab.gov.br/info-331agro/safras/graos/boletim-da-safra-de-graos

Cruz, J. C., Pereira Filho, I. A., Alvarenga, R. C., Gontijo Neto, M. M., Viana, J. H. M., Oliveira, M. F., \& Santana, D. P. (2006). Manejo da cultura do milho em sistema plantio direto. Informe Agropecuário, 27(1), 42-53.

Escola Superior de Agricultura Luiz de Queiroz - ESALQ. (2015). Visão Agrícola: Milho (Vol. 9, No. 13). Piracicaba, SP. Retrieved in 2020, Jan 25, from http://www.esalq.usp.br/visaoagricola/sites/default/files/Esalq-VA13-Milho.pdf

Fancelli, A. L., \& Dourado Neto, D. (2004). Produção de milho (2. ed., 360 p.). Guaíba: Agropecuária.

Fietz, C. R., Comunello, E., Ceccon, G., Flumignan, D., \& Sentelhas, P. (2012). Risco climático do consórcio milho com braquiária em Mato Grosso do Sul. In Ceccon, G. (Ed.), Consórcio milho-braquiária (pp. 89-112). Brasília: Embrapa.

Fornasieri Filho, D. (2017). Manual da cultura do milho (1. ed.) Jaboticabal: Funep.

Formigoni, I. (2017, Setembro 15). Preços históricos do milho no Brasil. Farmnews, Retrieved in 2019 , June 18, from http://www.farmnews.com.br/mercado/precos-historicos-do-milho/

Galvão, J. C. C., Borém, A., \& Pimentel, M. A. G. (2015). Milho: do plantio à colheita (2. ed., 351 p.). Viçosa, MG: Editora UFV. 
Garbelini, L. G., Franchini, J. C., Debiasi, H., Balbinot Junior, A. A., Betioli Junior, E., \& Telles, T. S. (2020). Profitability of soybean production models with diversified crops in the Autumn-Winter. Agronomy Journal, 112(5), 4092-4103. http://dx.doi.org/10.1002/agj2.20308

Garcia, R. A., Ceccon, G., Sutier, G. A. S., \& Santos, A. L. F. (2018). Soybean-corn succession according to seeding date. Pesquisa Agropecuária Brasileira, 53(1), 22-29. http://dx.doi.org/10.1590/s0100$204 \times 2018000100003$

Kamali, F. P., Meuwissen, M. P. M., de Boer, I. J. M., van Middelaar, C. E., Moreira, A., \& Lasink, A. G. J. M. O. (2017). Evaluation of the environmental, economic, and social performance of soyben farming systems in southern Brazil. Journal of Cleaner Production, 142, 385-394. http://dx.doi.org/10.1016/j.jclepro.2016.03.135

Lazzarini Neto, S. (1995). Controle da produção e custos (1. ed.). São Paulo: SDF Editores.

Martin, N. B., Serra, R., Oliveira, M. D. M., Angelo, J. A., \& Okawa, H. (1998). Sistema integrado de custos agropecuários. Custagri. informações econômicas - Governo do estado de São Paulo. Instituto de economia agrícola, 28(9), 7-28.

Matsunaga, M., Bemelmans, P. F., Toledo, P. E. N., Dulley, R. D., Okawa, H., \& Pedroso, I. A. (1976). Metodologia de custo de produção utilizado pelo IEA. Agricultura em São Paulo, 23(1), 123-139.

Melo, C. O., Silva, G. H., \& Esperancini, M. S. T. (2012). Análise econômica da produção de soja e de milho na safra de verão, no Estado do Paraná. Revista de Política Agrícola, 21(1), 121-132.

Nóia Júnior, R. S., \& Sentelhas, P. C. (2019). Soybean-maize succession in Brazil: Impacts of sowing dates on climate variability, yields and economic profitability. European Journal of Agronomy, 103, 140-151. http://dx.doi.org/10.1016/j.eja.2018.12.008

Robusti, E. A., Mazeto, V. A., Ventura, M. U., Soares Júnior, D., \& Menezes Junior, A. O. (2019). Soybean crop profitability: biodynamic vs conventional farming in a 7-yr case study in Brazil. Renewable Agriculture and Food Systems, 1(6), http://dx.doi.org/10.1017/ S1742170518000613

Silva Neto, S. P.S. (2011). Importância da cultivar de soja na viabilidade da sucessão soja - milho. Jornal Dia de Campo.

Seibert, R. M., Salla, N., Rusch, T. F. M.C., \& Rusch, J. (2014). Estudo de viabilidade econômico-financeira para implantação de uma estufa hidropônica em uma propriedade rural no interior de Santo Ângelo-RS. Research Gate, 2(3), 1-19.

Silveira, D. R. C., Kamikoga, T. M., Kamikoga, M. K., Terasawa, J. M., \& Romanek, C. (2008). Avaliação de cultivares de soja convencionais e Roundup Ready em duas épocas de semeadura em Ponta Grossa, PR. In Encontro de Engenharia e Tecnologia dos Campos Gerais (p. 4). Ponta Grossa.

Silva, A. G., Francischini, R., \& Sena Martins, P. D. (2015). Desempenhos agronômico e econômico de cultivares de milho na safrinha. Agrarian, 8(27), 1-11.

Trentin, R., Heldwein, A. B., Streck, N. A., Trentin, G., \& Silva J. C. (2013). Subperíodos fenológicos e ciclo da soja conforme grupos de maturidade e datas de semeadura. Pesquisa Agropecuária Brasileira, 48(7), 703-713.

Vernetti Junior, F. J., Gomes, A. S., \& Schuch, L. O. B. (2009). Sustentabilidade de sistemas de rotação e sucessão de culturas em solos de várzea no Sul do Brasil. Ciência Rural, 39(6), 1708-1714.

Volsi, B., Bordin, I., Higashi, G. E., \& Telles, T. S. (2020). Economic profitability of crop rotation systems in the Caiuá Sandstone Area. Ciência Rural, 50(2), http://dx.doi.org/10.1590/0103-8478cr20190264

Zanella, T. P., \& Leismann, E. L. (2017). Abordagem da sustentabilidade nas cadeias de commodities do agronegócio brasileiro a partir de sites governamentais. Revista Metropolitana de Sustentabilidade, 7(2), 6-19. 